\title{
The Trend Analysis of Major Food Grains in India
}

\author{
S.V. Halawar* \\ Karnatak Arts College, Dharwad, India \\ *Corresponding author
}

\section{A B S T R A C T}

\section{Keywords}

Food grains, Time series, Trend analysis, ANOVA, Correlation

Article Info

Accepted:

04 February 2019

Available Online:

10 March 2019
The present study attempt to provide credible estimates of future production of food grains (rice, wheat, coarse cereals, sugar cane and pulses) by testing differences in the production of different food grains, trend analysis and Correlation coefficient. It is estimated the correlation between the production of rice and wheat because of their major importance in India as an everyday food.

\section{Introduction}

Constant economic growth, increasing population and varying lifestyles are causing significant changes in Indian food basket, away from staple food grains towards highvalue horticultural and animal products (Kumar et al., 2007; Mittal, 2007). While per capita consumption of food grains has declined, their total consumption has increased due to growing population. Also, varies in the dietary pattern towards animal products have led to an increased demand of food grains as feed. Nonetheless, food grains mainly rice and wheat, continue to be the main pillars of India's food security (Praduman Kumar et al., 2009).
On the supply side, inspired by the public investment in irrigation and rural infrastructure and rapid spread of highproductive varieties of rice and wheat, together with enhanced crop production practices, India has achieved remarkable growth in food grain production. Per capita annual production of food grains increased from $183 \mathrm{~kg}$ during early-1970s to $207 \mathrm{~kg}$ by mid-1990s, even though country's population increased more than 50 percent during this era (Economics Survey, 2007). After mid-1990s, per capita food grain production started declining due to deceleration in the total factor productivity (TFP) growth (Kumar et al., 2004; Kumar and Mittal, 2006). It is a subject of concern for Indian food-security. 
This varying scenario of consumption and production will have a considerable influence on the demand and supply prospects of food.

\section{Food grain production}

India is constantly facing pressure on the demand side due to stable population growth, limited land availability, and a number of other production deterrents, which might also come into view as obstacles for the contribution of food grains. Indian government policies and planning has always given considerable importance to production of food grains due to which India has been achieving the continued growth despite many constraints. During the last decade (2000-01 to 2010-11), the areas under cereals, pulses, and oilseeds have increased by about 5.7, 6.0, and 4.0 million hectares, respectively, and the area under coarse cereals has declined by 2.6 million hectares. The area under wheat cultivation has accelerated extensively in comparison to other cereals and millets. However, a moderate deceleration in total grain cultivated area in association to pulses cultivated area was witnessed during the years of 2005 to 2011. The highest food grain production of 259.32 million tonnes was recorded in 2011-12. Out of the total food grains production, cereals accounted for 242.23 million tonnes and pulses 17.09 million tonnes. Production of rice and wheat was recorded at 105.3 and 94.9 million tonnes, respectively (Khatkar et al., 2016).

It was estimated that the agriculture sector in India is likely to grow by $5.2-5.7 \%$ in $2013-$ 14. India is one of the largest producers of cereal as well as the largest exporter of cereal products worldwide. India's export of cereals for the period of 2013-14 stood at Rs. 63452.09 crores. Rice occupies the most considerable share in India's total cereals export with $64.40 \%$ during this period. Countries such as Iran, Saudi Arabia, UAE,
Indonesia, and Bangladesh mainly imported cereals from India during 2013-14.

\section{Wheat}

The area and production under wheat has improved from 27.99 million hectares in 2006-07 to 29.86 million hectares in 2011-12 and from 75.81 million tonnes in 2006-07 to an all-time record high of 94.88 million tonnes in 2011-12, respectively. U. P. accounts for the maximum area under cultivation and production, whereas Punjab and Haryana are produce higher productivity with minimum landholding under wheat cultivation (Khatkar et al., 2016).

The increase in yield of wheat has been observed in the states of Haryana, Punjab, Madhya Pradesh, and Uttar Pradesh. The regular national productivity is about 2.9 tonnes per hectare. The major wheatproducing states are Uttar Pradesh, Punjab, Haryana, Madhya Pradesh, Maharashtra, Gujarat, Rajasthan, Bihar, Karnataka, West Bengal, Himachal Pradesh, Uttaranchal, and Jammu and Kashmir. These states contribute about $99.5 \%$ of total wheat production in the country. The remaining states, namely Jharkhand, Assam, Delhi, Chhattisgarh, and other northeastern states, contribute only about $0.5 \%$ of the total wheat production in the country. Among food grains, wheat in India stands next to rice both in area and production (Khatkar et al., 2016).

\section{Rice}

India is the $2^{\text {nd }}$ largest producer and consumer of rice in the world and accounts for $22.3 \%$ of universal production. Several programs run by the government such as National Food Security Mission (NFSM) launched during 2007-08 and Bringing Green Revolution in Eastern India (BGREI) during 2010-11 increased production and productivity of rice 
from 96.7 million tonnes and $2202 \mathrm{~kg} \mathrm{ha}^{-1}$ in 2007-08 to 105.31 million tonnes and 2393 $\mathrm{kg} \mathrm{ha}^{-1}$, respectively, in 2011-12. The NFSM is presently under implementation in 482 districts of 19 states of the country with a view to enhance the production of rice, wheat, and pulses through area development and productivity enhancement, restoring soil fertility and productivity, creating employment opportunities, and enhancing farm level economy to restore confidence of farmers. The basic strategy of the mission is to promote and extend improved technologies that is, seed, soil amendments, micronutrients, farm machinery, integrated pest management, and resource conservation technologies, along with capacity building of farmers with efficient monitoring and better management in the high-potential districts to bridge the yield gaps (Khatkar et al., 2016).

\section{Coarse cereals}

Crops like sorghum, ragi, millets, and other small millets (kudo, sanwa, kutiki, and foxtail) termed as coarse cereals have been the primary components of the food bag of rural India. Rain-fed regions of India like Karnataka, Tamil Nadu, Maharashtra, Madhya Pradesh, Gujarat, and Rajasthan are best suited for coarse cereal crops, and coarse cereals are therefore cultivated predominantly in these areas. A downturn has been witnessed in the area covered under coarse cereals cultivation from 29.03 million hectares in 2004-05 to 26.42 million hectares in 2011-12. Significantly increases in the production of coarse cereals have been witnessed from $1153 \mathrm{~kg} \mathrm{ha}^{-1}$ in 2004-05 to $1591 \mathrm{~kg} \mathrm{ha}^{-1}$ in 2011-12. Production of coarse cereals in 2004-05 was 33.46 million tonnes, which increased to a maximal level of 43.40 million tonnes in 2010-11 but decreased slightly to 42.04 million tonnes in 2011-12 mainly because of a shift in area of cultivation to other competing crops.

\section{Pulses}

Pulses complement the staple cereal in the diet as a gifted resource of proteins, essential vitamins, amino acids, and minerals among the vegetarians in India. They contain 22$24 \%$ protein, which is almost twice the protein in wheat and three times that of rice. India is the leading producer in the world with $25 \%$ of the total share and is also the largest receiver and consumer in the world. Most of the pulses grown in India include Bengal gram or gram, lentil, red gram, black gram, green gram, moth bean, cowpea, horse gram, and faba bean. Most popular among these are Bengal gram, red gram, black gram, lentil, and green gram. Maharashtra, Madhya Pradesh, Uttar Pradesh,

Karnataka, Andhra Pradesh, and Rajasthan are the major states growing pulses in India. These six states supply $70 \%$ of total pulse production and area. The country has achieved a record pulses production of 19.57 million tonnes in 2013-14 compared to 18.34 million tonnes in the year 2012-13. Production of all the pulses, as a whole has been increasing year by year except for a decline in 2011-12. The production of black gram only has been estimated to decline from 1.9 million tonnes in $2012-13$ to 1.5 million tonnes in 2013-14.

\section{Consumption of food grains}

If we observe the rate of growth of population and food grains production for last five decades in India, it has been observed that the population growth rate has seen a downfall from $2.24 \%$ to $1.03 \%$. The overall rate of production of food grains has also declined, it is raised only during the period from 198191. During 2004-05 total cereal consumption showed a rise of about $100 \mathrm{~g}$ per person per month in rural areas and a fall of $350 \mathrm{~g}$ per person per month in urban areas. The per 
capita consumption trend of grains such as pearl millet, sorghum, and maize has been higher in the rural sector as compared to a decreasing trend in consumption of major grains like rice and wheat. The cereals other than rice and wheat contributed $1 \mathrm{~kg}$ per person per month in rural India and $0.8 \mathrm{~kg}$ per person per month in urban India in 2011-12.

\section{Materials and Methods}

In the present paper secondary data is collected from agricultural situation in India February 2018(Agricultural situation in India February 2018). The data related to production of major food grains, pulses, oilseeds and cotton. To study the behavior of the data we used the statistical techniques like trend analysis, Analysis of variance and line charts.

\section{Results and Discussion}

\section{Data analysis}

From Figure 1, 2 and 3 trend analysis of major food grains, sugar cane and crops, it is observed the trend is declined i.e. the production of food grains, sugar cane and crops are decreasing year by year. We can observe in case of food grains, total pulses and oilseeds the maximum production during the year 2016-17 and again it is reduced in 2017-18 (Fig. 4).

In case of sugarcane production is constant but during the year 2016-17 it is declined to 310 million tones later again it is recovered in 2017-18. From table 1 the predicted trend values are declining in all the cases (Food grains, Pulses, Oilseeds and sugarcane).

$\mathrm{H}_{0}$ : There is no difference in the production of different food grains.

$\mathrm{H}_{1}$ : There is a difference in the production of different food grains.

\section{Post Hoc tests}

\section{Homogeneous subsets}

\section{Plots}

The analysis of variance is used for testing significant difference between group of means. It is observed from the ANOVA table (Table 2) that the significance value is 0.000 (i.e., $p=0.000$ ), which is less than 0.05. That is the factors means are differing at $5 \%$ level of significance and null hypothesis $\left(\mathrm{H}_{0}\right)$ is rejected. To verify, which of the specific groups are differed significantly it is tested the Tukey post hoc test, here we obtained the Multiple Comparisons table (Table 3) which contains the $\mathrm{p}$ values of each pair and homogeneous groups of non significant variables.

It is observed from the above given homogeneous subsets, first, second, third and fourth subsets contains the factor total pulses, total coarse cereals, wheat and rice with $\mathrm{P}$ value 1.000 respectively, this shows that the factors are significantly differing from all other factors, so the yield of every food grains is totally varied from factor to factor. From the Means plot it is observed the same scenario as in the homogeneous groups. It is clear from the means plot that total pulse production is minimum and rice production is maximum. This analysis tells that there is significant difference between the food grains (Table 4).

Karl Pearson correlation coefficient is found to be positive, it indicates that the rice and wheat are production having same degree change in the year wise production and they are varying in same direction. But as per the $\mathrm{P}$ value they are independent. This result indicates even though rice and wheat are daily food of Indians but there production is not in same quantity (Table 5). 
Table.1 Production of major food grains year wise

\begin{tabular}{|l|r|r|r|l|l|l|r|r|}
\hline Year & $\begin{array}{l}\text { Total } \\
\text { Food } \\
\text { grains }\end{array}$ & \multicolumn{1}{l|l|}{ Rice } & Wheat & $\begin{array}{l}\text { Total } \\
\text { Coarse } \\
\text { Cereals }\end{array}$ & $\begin{array}{l}\text { Total } \\
\text { Pulses }\end{array}$ & $\begin{array}{l}\text { Total } \\
\text { Oilseeds }\end{array}$ & Sugarcane & Cotton \\
\hline $\mathbf{2 0 1 2 - 1 3}$ & 257.1 & 105.2 & 93.5 & 40 & 18.3 & 30.9 & 341.2 & 34.2 \\
\hline $\mathbf{2 0 1 3 - 1 4}$ & 265 & 106.7 & 95.9 & 43.3 & 19.3 & 32.8 & 352.1 & 35.9 \\
\hline $\mathbf{2 0 1 4 - 1 5}$ & 252 & 105.5 & 86.5 & 42.9 & 17.2 & 27.5 & 356.3 & 37.8 \\
\hline $\mathbf{2 0 1 5 - 1 6}$ & 251.6 & 104.4 & 92.3 & 38.5 & 16.4 & 25.3 & 348.4 & 30 \\
\hline $\mathbf{2 0 1 6 - 1 7}$ & 275.7 & 110.2 & 98.4 & 44.2 & 23 & 32.1 & 306.7 & 33.1 \\
\hline $\mathbf{2 0 1 7 - 1 8}$ & 228.02 & 94.5 & 93.32 & 31.5 & 8.7 & 20.7 & 337.7 & 32.3 \\
\hline $\mathbf{2 0 1 8}-19$ & $243.56^{*}$ & $100^{*}$ & $94.55^{*}$ & $35.65^{*}$ & $13.44^{*}$ & $22.68^{*}$ & $323.9^{*}$ & $31.36^{*}$ \\
\hline $\mathbf{2 0 1 9 - 2 0}$ & $240.32^{*}$ & $98.74^{*}$ & $94.91^{*}$ & $34.39^{*}$ & $12.38^{*}$ & $21.1^{*}$ & $319.3^{*}$ & $30.64^{*}$ \\
\hline
\end{tabular}

Table.2

\begin{tabular}{|l|c|c|c|c|c|}
\hline \multicolumn{4}{|c|}{ ANOVA } \\
\hline $\begin{array}{c}\text { Sum of } \\
\text { Squares }\end{array}$ & df & $\begin{array}{c}\text { Mean } \\
\text { Square }\end{array}$ & F & Sig. \\
\hline $\begin{array}{l}\text { Between } \\
\text { Groups }\end{array}$ & 31563.734 & 3 & 10521.245 & 475.660 & .000 \\
\hline Within Groups & 442.385 & 20 & 22.119 & & \\
\hline Total & 32006.119 & 23 & & & \\
\hline
\end{tabular}

Table.3 Tukey HSD

\begin{tabular}{|c|c|c|c|c|c|c|}
\hline \multicolumn{7}{|c|}{ Multiple Comparisons } \\
\hline \multirow[t]{2}{*}{ (I) Gpvr } & \multirow[t]{2}{*}{ (J) Gpvr } & \multirow{2}{*}{$\begin{array}{c}\text { Mean } \\
\text { Difference } \\
\text { (I-J) }\end{array}$} & \multirow[t]{2}{*}{ Std. Error } & \multirow[t]{2}{*}{ Sig. } & \multicolumn{2}{|c|}{ 95\% Confidence Interval } \\
\hline & & & & & $\begin{array}{l}\text { Lower } \\
\text { Bound }\end{array}$ & Upper Bound \\
\hline \multirow[t]{3}{*}{ Rice } & Wheat & $11.09667^{*}$ & 2.71534 & .003 & 3.4966 & 18.6967 \\
\hline & $\begin{array}{l}\text { Total coarse } \\
\text { cereals }\end{array}$ & $64.35000^{*}$ & 2.71534 & .000 & 56.7499 & 71.9501 \\
\hline & Total pulses & $87.26667^{*}$ & 2.71534 & .000 & 79.6666 & 94.8667 \\
\hline \multirow[t]{3}{*}{ Wheat } & Rice & $-11.09667^{*}$ & 2.71534 & .003 & -18.6967 & -3.4966 \\
\hline & $\begin{array}{l}\text { Total coarse } \\
\text { cereals }\end{array}$ & $53.25333^{*}$ & 2.71534 & .000 & 45.6533 & 60.8534 \\
\hline & Total pulses & $76.17000^{*}$ & 2.71534 & .000 & 68.5699 & 83.7701 \\
\hline \multirow{3}{*}{$\begin{array}{l}\text { Total coarse } \\
\text { cereals }\end{array}$} & Rice & $-64.35000^{*}$ & 2.71534 & .000 & -71.9501 & -56.7499 \\
\hline & Wheat & $-53.25333^{*}$ & 2.71534 & .000 & -60.8534 & -45.6533 \\
\hline & Total pulses & $22.91667^{*}$ & 2.71534 & .000 & 15.3166 & 30.5167 \\
\hline \multirow[t]{3}{*}{ Total pulses } & Rice & $-87.26667^{*}$ & 2.71534 & .000 & -94.8667 & -79.6666 \\
\hline & Wheat & $-76.17000^{*}$ & 2.71534 & .000 & -83.7701 & -68.5699 \\
\hline & $\begin{array}{l}\text { Total coarse } \\
\text { cereals }\end{array}$ & $-22.91667^{*}$ & 2.71534 & .000 & -30.5167 & -15.3166 \\
\hline
\end{tabular}


Table.4 Tukey HSD

\begin{tabular}{|c|c|c|c|c|c|}
\hline \multirow[t]{2}{*}{ Gpvr } & \multirow[t]{2}{*}{$\mathrm{N}$} & \multicolumn{4}{|c|}{ Subset for alpha $=0.05$} \\
\hline & & 1 & 2 & 3 & 4 \\
\hline Total pulses & 6 & 17.1500 & & & \\
\hline Total coarse cereals & 6 & & 40.0667 & & \\
\hline Wheat & 6 & & & 93.3200 & \\
\hline Rice & 6 & & & & 104.4167 \\
\hline Sig. & & 1.000 & 1.000 & 1.000 & 1.000 \\
\hline \multicolumn{6}{|c|}{ Means for groups in homogeneous subsets are displayed. } \\
\hline \multicolumn{6}{|c|}{ a. Uses Harmonic Mean Sample Size $=6.000$. } \\
\hline
\end{tabular}

Table.5 Correlation between Rice and Wheat

\begin{tabular}{|l|l|c|c|}
\hline \multirow{2}{*}{ Rice } & Pearson Correlation & 1 & .266 \\
\cline { 2 - 4 } & Sig. (2-tailed) & & .610 \\
\cline { 2 - 4 } & N & 6 & 6 \\
\hline \multirow{2}{*}{ Wheat } & Pearson Correlation & .266 & 1 \\
\cline { 2 - 4 } & Sig. (2-tailed) & .610 & \\
\hline & N & 6 & 6 \\
\hline
\end{tabular}

Fig.1 Trends of Major food grains

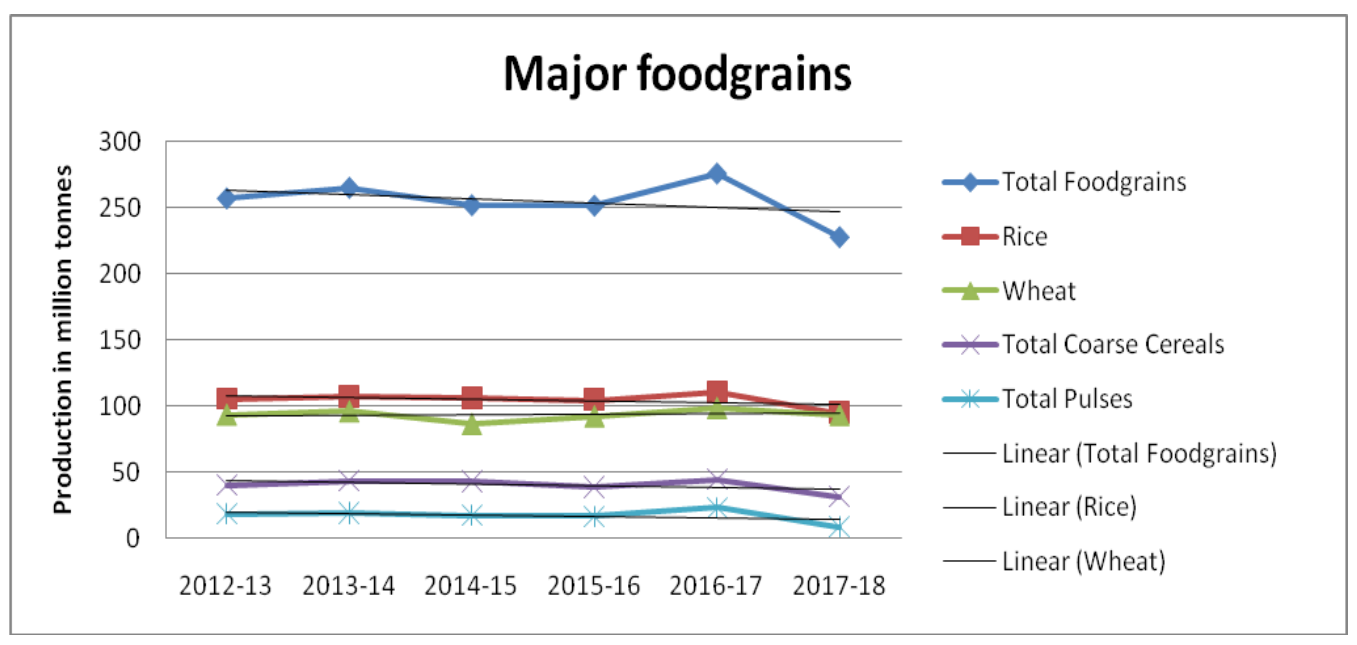


Fig.2 Year wise production and trend analysis of sugar cane

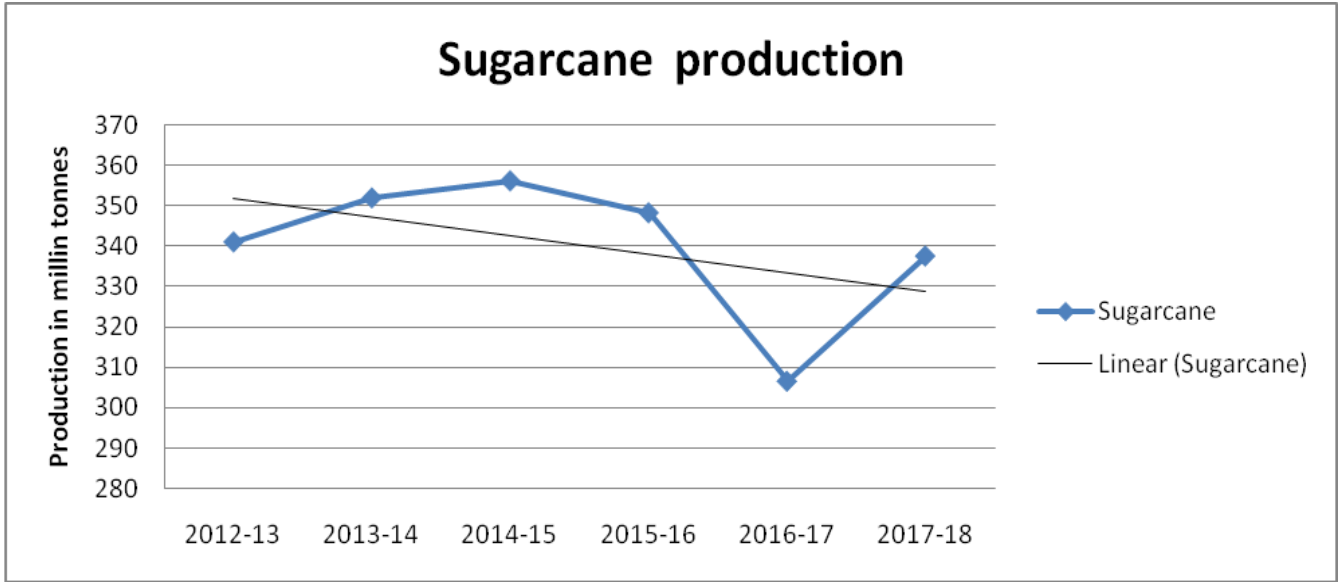

Fig.3 Year wise production of major crops of India and trend analysis

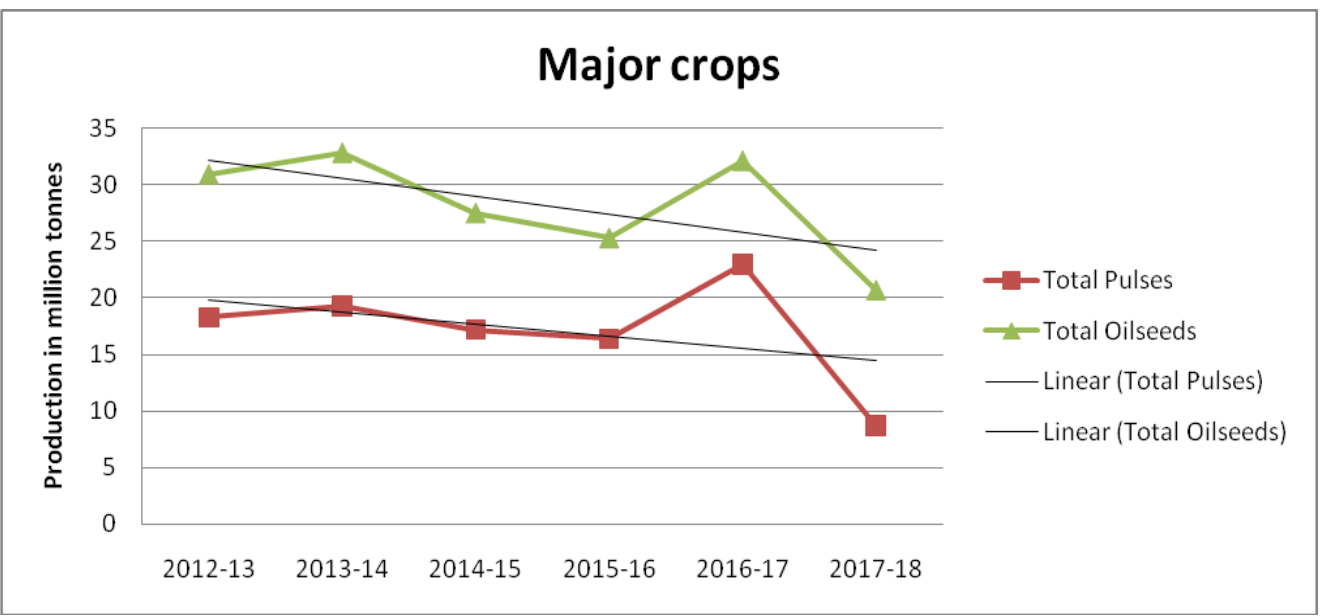

Fig.4 Means

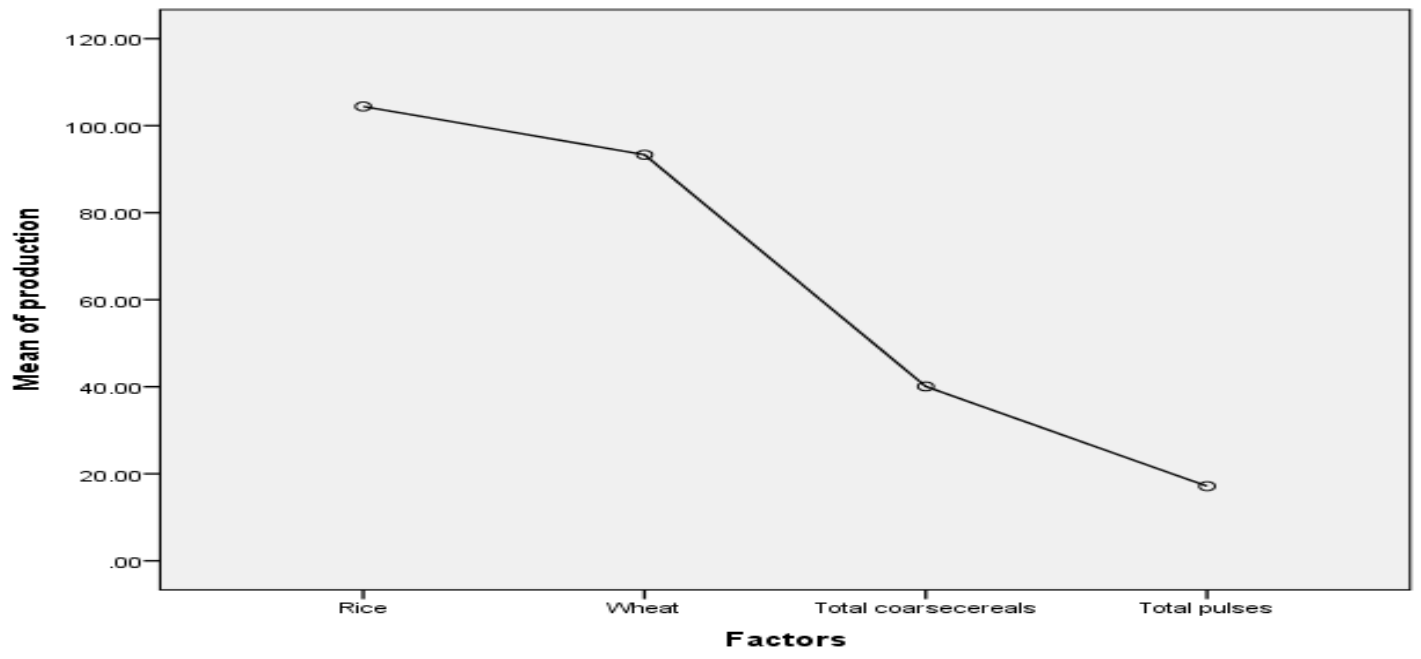


It is concluded in this paper, we have studied about production of major food grains like rice, wheat, pulses, oilseeds and sugar cane in India. Here it is derived the results by using the statistical techniques like trend analysis for prediction future production and analysis of variance for testing difference in the production of different food grains and we also observed the correlation between rice and wheat it is found slightly positive correlation between them and these two food grains are non-significance in production even though rice and wheat are daily routine food of Indians but there production is not in same quantity.

\section{References}

Agricultural situation in India February 2018, The controller of publication, Civil lines Dehli.pp.1-66

Government of India (2007) Economic Survey, 2006-07, Ministry of Finance, New Delhi.
Khatkar, BS, N Chaudhary, and Dangi, G. J. (2016) Production and Consumption of Grains: India University of Science and Technology, Hisar, India, vol. 1, pp. 367373.

Kumar, Praduman and Mittal, Surabhi (2006) Agricultural productivity trend in India: Sustainability Issues. Agricultural Economics Research Review, 19 (Conference No.): 71-88.

Kumar, Praduman, Kumar, Anjani and Mittal, Surabhi (2004) Total factor productivity of crop sector in the Indo-Gangetic Plain of India: Sustainability issues revisted. Indian Economic Review, 34(1): 169-201.

Kumar, Praduman, Mruthyunjaya and Dey, Madan M. (2007) Long-term changes in food basket and nutrition in India, Economic and Political Weekly, (September 1): 3567-3572.

Mittal, Surabhi (2007) What affect changes in cereal consumption. Economic and Political weekly (February): 444 447.

\section{How to cite this article:}

Halawar, S.V. 2019. The Trend Analysis of Major Food Grains in India. Int.J.Curr.Microbiol.App.Sci. 8(03): 353-360. doi: https://doi.org/10.20546/ijcmas.2019.803.044 